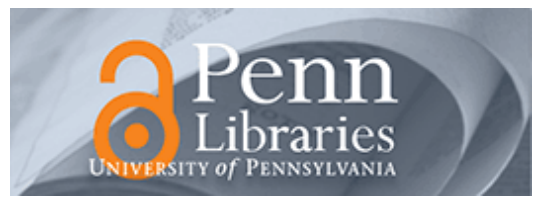

University of Pennsylvania

ScholarlyCommons

Marketing Papers

Wharton Faculty Research

$10-2016$

\title{
The PollyVote Forecast for the 2016 American Presidential Election
}

Andreas Graefe

Randall J. Jones

J. Scott Armstrong

University of Pennsylvania, armstrong@wharton.upenn.edu

Alfred G. Cuzán

Follow this and additional works at: https://repository.upenn.edu/marketing_papers

Part of the American Politics Commons, Marketing Commons, Models and Methods Commons, and the Social Influence and Political Communication Commons

\section{Recommended Citation}

Graefe, A., Jones, R. J., Armstrong, J. S., \& Cuzán, A. G. (2016). The PollyVote Forecast for the 2016 American Presidential Election. PS: Political Science \& Politics, 49 (4), 687-690. http://dx.doi.org/10.1017/ S1049096516001281

This paper is posted at ScholarlyCommons. https://repository.upenn.edu/marketing_papers/370

For more information, please contact repository@pobox.upenn.edu. 


\title{
The PollyVote Forecast for the 2016 American Presidential Election
}

\author{
Abstract \\ The PollyVote applies a century-old principle of combining different evidence-based methods for \\ forecasting the outcome of American presidential elections. In this article, we discuss the principles \\ followed in constructing the PollyVote formula, summarize its components, review the accuracy of its \\ previous forecasts, and make a prediction for this year's presidential election. \\ Disciplines \\ American Politics | Business | Marketing | Models and Methods | Social Influence and Political \\ Communication
}




\title{
The PollyVote Forecast
}

\section{for the 2016 American Presidential Election}

Forthcoming (subject to changes) in PS: Political Science \& Politics

\author{
Andreas Graefe \\ Randall J. Jones, Jr. \\ J. Scott Armstrong \\ Alfred G. Cuzán
}

\begin{abstract}
The PollyVote applies a century-old principle of combining different evidencebased methods for forecasting the outcome of American presidential elections. In this article, we discuss the principles followed in constructing the PollyVote formula, summarize its components, review the accuracy of its previous forecasts, and make a prediction for this year's presidential election.
\end{abstract}

\section{Introduction}

The PollyVote is an evidence-based formula designed to forecast election outcomes founded on methodological improvements in forecasting practices. Forecasting error is reduced by combining forecasts within and across different methods, equally weighted. Following this rule, the PollyVote has accurately forecast the outcome of the last three presidential elections by as much as a year in advance of Election Day. Updated twice a week in 2004 (Cuzán, Armstrong and Jones, 2005a, 2005b) and in subsequent elections at least once daily, at no time has the PollyVote 
called the election for any other than the winner. Moreover, in every one of the 100 days prior to Election Day, the PollyVote forecast was more accurate than any of its component methods (Graefe et. al, 2009, 2014a, 2014b). In the sections that follow, we successively elucidate the combination principles use in the PollyVote, summarize the methods incorporated into it, review its performance at forecasting presidential elections, issue a forecast for $\mathbf{2 0 1 6}$, and conclude with some remarks on nature of the PollyVote and its uses.

\section{Combining Forecasts}

The primary reason for why the PollyVote combines forecasts from different methods is the following. It is difficult to determine a priori which individual method will provide the best forecasts for a given election or for a given day prior to an election. Every election is held in a different context and has its idiosyncrasies. As a result, a method that worked well in the past might not work in future elections. Also, a method that worked well 100 days before an election might not work as well in another election or even 30 days before the same election. Combining forecasts from different methods that rely on different information is well-established as a method to reduce errors arising from those sources. This is one of the major findings in forecasting research over the past half a century (Armstrong, Green, and Graefe 2015). Combining incorporates different information generated by each method, thus including more information than any individual method. Systematic and random errors of individual forecasts tend to cancel out in the aggregate, particularly when the individual forecasts draw on different information, bracket the true value, and are uncorrelated (Graefe et al. 2014b).

\section{Equal Weights}


Research has shown that, apart from being easy to understand, equal weights are difficult to beat by more complex approaches to combining which aim to estimate "optimal" weights for the components. These findings hold both for weighting the predictor variables in linear models (Cuzán and Bundrick 2009, Graefe 2015b) as well as combining forecasts from different models (Graefe et al. 2015). One reason for the strong performance of equal weights is the fact that the accuracy of the component forecasts varies over time and may be impacted by exogenous effects. Another more technical reason is error in estimating the weights. In general, the simple average will be more accurate than estimated "optimal" weights if two conditions are met: first, the combination is based on a large number of individual forecasts and, second, the optimal weights are close to equality. In such situations, each forecast has a small weight, and the simple average provides an efficient tradeoff against the error that arises from the estimation of weights (Graefe et al. 2015).

The PollyVote Formula

The PollyVote combines forecasts within and across six different component methods in the following manner. First, we calculate a combined forecast for each component method, then apply equal weights to calculate the simple average across the component forecasts. This does not mean that every forecast used in calculating the PollyVote is weighted equally with every other forecast. For example, there is only one prediction market that predicts the national popular vote, so there is one forecast available for that component method. On the other hand, there are several regression models, each producing its own forecast. If we used a simple average of all available forecasts, that would over-represent models and grossly underrepresent prediction 
markets. In short, we seek to equalize the impact of each component method rather than each individual forecast.

\section{The Components of the PollyVote}

The 2016 PollyVote is derived by averaging forecasts within and across six different component methods:

1. Trial heat polls

2. $\quad$ Prediction markets

3. Econometric models

4. $\quad$ Expert judgment

5. Index models

6. Citizen forecasts

The first four methods comprised the original specification of the PollyVote used in 2004 (Cuzán, Armstrong, and Jones 2005) and 2008 (Graefe et al. 2009). In 2012, index models were added to the formula (Graefe et al. 2014a), and citizen forecasts are included for the first time in this year's forecast. Each component method has been shown in research findings to be an appropriate and accurate election predictor.

\section{Polls - Vote Intention Surveys}

Vote intention surveys-trial heat polls-are most prevalent and highly visible in the news media coverage. The method asks respondents a variation of this question: "If the election for President were held today, who would you vote for: Donald Trump, the Republican, or Hillary Clinton, the Democrat?” The PollyVote relies on several poll aggregators, each of which collects and aggregates results from individual polls. In order to calculate its combined poll component, the PollyVote averages the forecasts across the different poll aggregators. On August 1, PollyVote's combined poll component 
predicts the Democratic nominee Hillary Clinton to achieve 50.6\% of the popular twoparty vote.

\section{Citizen Forecasts - Vote Expectation Surveys}

Rather than asking who respondents themselves intend to vote for, vote expectation surveys-also referred to as citizen forecasts (Lewis-Beck and Skalaban 1989) - ask people who they expect to win the election. A typical question is phrased like this: "Who do you think will win the U.S. presidential election, Donald Trump or Hillary Clinton?” The aggregate responses are then used to predict the election winner.

Though often overlooked, citizen forecasts are highly accurate predictors of election outcomes (Graefe 2014). In 89\% of 217 surveys administered between 1932 and 2012, a majority of respondents correctly predicted the winner. Regressing the incumbent share of the two-party vote on the percent of respondents who expect the incumbent party ticket to win accounts for two-thirds of the variance. Moreover, in the last 100 days of the previous seven presidential elections, vote expectations provided more accurate forecasts than vote intention polls, prediction markets, econometric models, and expert judgment. Compared to a typical poll, for example, vote expectations reduced the error on average by about $50 \%$.

An ex post analysis for the six elections from 1992 to 2012 further showed that adding vote expectations to the PollyVote would have reduced forecast error by seven percent (Graefe 2015a). Given this extensive validation work, we have added vote expectations as a sixth component to the PollyVote for forecasting the 2016 election. First, we translate the results of vote expectation surveys into a two-party vote share prediction using the vote equation estimated by Graefe (2014). Then, we calculate the combined component forecast by exponential smoothing, where the most recent citizen 
forecast is assigned a weight of thirty percent. On August 1, PollyVote's citizen forecast component predicts Hillary Clinton to gain $51.7 \%$ of the two-party vote.

\section{Prediction Markets}

Prediction markets are another expression of people's expectations of who will win. Yet, instead of asking a representative sample for their opinion, prediction markets are open for anyone to participate. And, people reveal their opinion by betting money on the election outcome. The resulting betting odds can then be interpreted as the market forecast. Most available markets provide probability forecasts for the candidates' likelihood to win. However, the PollyVote requires a national popular vote share prediction. We know of only one prediction market, the University of Iowa's Iowa Electronic Market (IEM), which provides such a forecast. Graefe (2017) reviewed prediction market accuracy for providing vote-share forecasts for elections in different countries. He found that prediction markets tend to outperform expert judgment as well as forecasts based on quantitative models and trial-heat polls, although compared to citizen forecasts the evidence was mixed. Also, the markets' advantage over polls diminishes if raw polls are converted into projections of the election outcome, as Erikson and Wlezien previously shows (2008).

The PollyVote uses the IEM's daily market prices but calculates one-week rolling averages in order to account for short-term fluctuations. This procedure has been used since 2004. On August 1, the IEM one-week rolling predicts Clinton to gain 52.0\% of the two-party vote.

\section{Expert Judgment}

The PollyVote includes the judgment of prominent academics and some practitioners knowledgeable of American politics who do not, however, have authored a 
forecasting model. Experts have been shown to be more accurate than polls or the IEM early in the election season, when the election is still nine months to a year or more away (Jones and Cuzán 2013). In 2016, a panel of 15 experts formed by the PollyVote

team has been polled monthly, and the mean forecast is incorporated into the PollyVote. On August 1, the combined expert forecast expects Clinton to achieve $54.2 \%$ of the twoparty vote, which makes it the most optimistic about Clinton's chances.

\section{Regression Models}

For the past several presidential election cycles at least a dozen political scientists and economists have computed regression equations to forecast the election results (Campbell 2013, Jones 2008). Many of the models use economic data through the second quarter of the election year, the first official estimate of which becomes available in late July. Thus forecasts from those models are made shortly after that. There are exceptions, however. The predictions of some models are available well before then, even two years ahead of the election, while at least one is delayed until the first polls after Labor Day are released (Campbell 2013). As these forecasts become available, they are averaged into a combined regression model component and incorporated into the PollyVote. On August 1, this component forecasts Clinton to receive 49.1\% of the twoparty vote, which makes it the only component that expects Trump to win the popular vote.

\section{Index Methods}

Benjamin Franklin may have been the original inventor of what he called "moral algebra" (Franklin 1956). He advised that before making a decision to do or not to do something of importance, one should list all possible considerations involved in the decision, assign a positive or negative value to each, weigh them according to their 
relative importance, and sum them. If the result was positive, proceed with the decision, but desist is the total was negative. Index models are appropriate in situations in which (a) a large number of variables are important and (b) there is good prior knowledge about the directional effect of each variable on the phenomenon of interest (Armstrong and Cuzán 2006, Graefe 2015b). In the context of election forecasting, indexes are typically constructed based on ratings of specific characteristics of candidates or events. Ratings can be made by experts or members of the public (e.g., based on survey data) and typically cover factors such as the candidates' biographic information, leadership skills, or issue-handling competences (Graefe 2013, Armstrong and Graefe 2011), as well as exogenous effects, such as economic performance or the presence of a third party (Lichtman 2008). Point forecasts of an election are provided by inserting current data into an equation specified by regressing the vote on the respective index scores. Currently forecasts from five index models are averaged to calculate the PollyVote's combined index model component. On August 1, this component predicts Clinton to achieve $53.5 \%$ of the popular two-party vote.

\section{The PollyVote Record}

As shown in Table 1, the PollyVote has performed highly accurately over the last six presidential elections, three times retrospectively and three times prospectively, in real time. On average, across three periods in the election cycle $(100,60$, and 30 days ahead of the election), the Mean Absolute Error (MAE) of the forecast is less than 2 percentage points. In the last three elections, in which true ex ante forecasting took place, the MAE is even lower, less than 1 percentage point. As far as we know, this record is unsurpassed by any other forecasting formula. 
Table 1 about here

\section{The PollyVote Forecast for 2016}

As of July 31, 100 days before the election, the PollyVote point forecast is for the Democratic candidate to win $51.9 \%$ of the two-party vote. Again as shown in Table 1, the MAE of the PollyVote ex ante forecasts was 1.4 percentage points. Assuming that this year the error will be close to the average, as of August 1 it is expected that the actual share of the vote for the Democratic ticket will fall somewhere between $50.5 \%$ and $53.3 \%$ of the two-party vote.

\section{Conclusion}

Having described the PollyVote and its remarkable record in forecasting presidential election outcomes and issued a forecast for this year's presidential election, we conclude with a few words on the nature of the PollyVote and its uses.

As we have seen, the PollyVote draws information generated by others with different methods, and averages all forecasts within and across methods to make a forecast. Thus, with the exception of the expert panel's forecast, it does not add any new information to the mix. Neither does it compete with any individual model, nor offer a theory for explaining the outcomes of elections in general. Rather, it aggregates all relevant information generated by all models and methods in a simple and straightforward manner. Thus, analogizing from biology, the PollyVote is a form of commensalism. Also, the PollyVote is democratic. By that we mean that the formula is available to one and all to make their own forecast. Attentive members of the public do 
not have to be elections or even forecasting experts to essay a prediction. All they have to do is diligently to collect information from different forecasting methods, most of which is available for free on the web, and combine it according to the same formula. Finally, the PollyVote is educational. In collecting and aggregating forecasts from different evidence-based methods, the platform provides a valuable source for those interested in elections and elections forecasting. At http://PollyVote.com, where the visitor will find not only the day's forecast, but all data used to generate the Pollyvote

forecasts on all presidential elections since 1992, as well as links to previous papers and articles associated with this work.

\section{References}

Armstrong, J. Scott. 2001. “Combining Forecasts." In Principles of Forecasting: A Handbook for Researchers and Pracitioners. J. Scott Armstrong, Editor. New York: Springer, 417-439.

Armstrong, J. Scott, and Alfred G. Cuzán. 2006. "Index Methods for Forecasting: An Application to the American Presidential Elections.” Foresight: International Journal of Applied Forecasting, 3, 10-13.

Armstrong, J. Scott, and Andreas Graefe. 2011. "Predicting Elections from Biographical Information about Candidates: A Test of the Index Method.” Journal of Business Research 64(7): 699-706.

Armstrong, J. Scott, Kesten C. Green, and Andreas Graefe. 2015. "Golden Rule of Forecasting: Be Conservative," Journal of Business Research, 68, 8, 1717-1731. Campbell, James E. 2013 “Recap: Forecasting the 2012 Election,” PS: Political Science and Politics, 46, 1, 37. 
Cuzán, Alfred G., J. Scott Armstrong, and Randall J. Jones Jr. 2005a. “How we Computed the PollyVote." Foresight: The International Journal of Applied Forecasting 1(1): 51-52.

Cuzán, A. G., Armstrong, J. S. \& Jones, R. J. Jr. (2005b). The PollyVote: Applying the Combination Principle in Forecasting to the 2004 Presidential Election, Paper presented at the 2005 International Symposium on Forecasting, San Antonio.

Cuzán, Alfred G. and Charles M. Bunddrick. 2009. "Predicting Presidential Elections with Equally Weighted Regressors in Fair's Equation and the Fiscal Model.” Political Analysis, 17, 3, 333-340.

Franklin, Benjamin. 1956. "Benjamin Franklin's 1772 letter to Joseph Priestley." Available: http://www.procon.org/view.backgroundresource.php?resourceID $=1474$.

Graefe, Andreas. 2013. "Issue and Leader Voting in U.S. Presidential Elections." Electoral Studies 32(4): 644-57.

Graefe, Andreas. 2014. “Accuracy of Vote Expectation Surveys in Forecasting Elections.” Public Opinion Quarterly 78(S1): 204-32.

Graefe, Andreas. 2015a. "Accuracy Gains of Adding Vote Expectation Surveys to a Combined Forecast of US Presidential Election Outcomes." Research \& Politics 2(1): $1-5$.

Graefe, Andreas. 2015b. "Improving forecasts using equally weighted predictors." Journal of Business Research, 68, 8, 1792-1799.

Graefe, Andreas, and J. Scott Armstrong. 2012. "Predicting Elections from the Most Important Issue: A Test of the Take-the-Best Heuristic.” Journal of Behavioral Decision Making 25(1): 41-48. . 2013. "Forecasting Elections from Voters' Perceptions of Candidates" Ability to Handle Issues.” Journal of Behavioral Decision Making, 26(3), 295303. 
Graefe, Andreas, J. Scott Armstrong, Randall J. Jones Jr., and Alfred G. Cuzán. 2014a. "Combining Forecasts: An Application to Elections." International Journal of Forecasting 30(1): 43-54. . 2014b. "Accuracy of Combined Forecasts for the 2012 Presidential

Elections: The PollyVote.” PS: Political Science \& Politics 47(2): 427-31. . 2013. "Combined forecasts of the 2012 election: The PollyVote."

Foresight - The International Journal of Applied Forecasting, 28, 50-51. . 2009. "Combined Forecasts of the 2008 Election: The PollyVote."

Foresight: The International Journal of Applied Forecasting, 12, 41-42.

Jones, Randall J., Jr. 2008. “The state of presidential election forecasting: The 2004 experience." International Journal of Forecasting, 24, 2, 189-322.

Jones, Randall J., Jr., and Alfred G. Cuzán. 2013. "Expert Judgment in Forecasting American Presidential Elections: A Preliminary Evaluation.” Presented at the 2013 meeting of the American Political Science Association, Chicago.

Lewis-Beck, Michael S. and Andrew Skalaban. 1989. "Citizen Forecasting: Can Voters See into the Future?” British Journal of Political Science, 19, 1, 146-153.

Lichtman, Alan .J. 2005 “The keys to the White House: An Index Forecast for 2008." International Journal of Forecasting, 24, 2, 301-309. 


\section{ABOUT THE AUTHORS}

J. Scott Armstrong is Professor at the Wharton School. He is founder of the Journal of Forecasting, International Journal of Forecasting, the International Symposium on Forecasting, and the PollyVote project, the creator of forecastingprinciples.com, and editor of Principles of Forecasting (2001). In 2010, he was listed as one of the 25 Most Famous College Professors Teaching Today.

Alfred G. Cuzán is a distinguished university professor at The University of West Florida. With R. J. Heggen and C. M. Bundrick, he developed the fiscal model of presidential elections. Along with J. S. Armstrong and R. J. Jones, Jr., he co-founded the PollyVote project. His most recent work addresses first principles of government (e.g., "Five Laws of Politics,” PS: Political Science and Politics, July 2015, 415-419.). Andreas Graefe is a research fellow at the Tow Center for Digital Journalism at Columbia University and LMU Munich's Department of Communication Studies and Media Research. He holds the endowed Sky Professorship in Customer Relationship Management at Macromedia University Munich. As leader of the PollyVote project, Andreas has done extensive validation work on election forecasting methods and has developed several election forecasting models.

Randall J. Jones, Jr., is Professor of Political Science, Emeritus at the University of Central Oklahoma, where he teaches election forecasting and conducts research in that field. He is the author of Who Will Be in the White House? Predicting Presidential Elections (Longman, 2002), co-founder of the PollyVote project, and founder of the Political Forecasting Group of the American Political Science Association. 


\begin{tabular}{|c|c|c|c|c|c|}
\hline \multicolumn{6}{|c|}{$\begin{array}{l}\text { Table 1. PollyVote Forecast Accuracy, 1992-2012: Mean Absolute } \\
\text { Error (MAE) at 100, 60, and } 30 \text { days before the election }\end{array}$} \\
\hline \multirow[t]{2}{*}{ Year } & \multirow[t]{2}{*}{ Incumbent Vote } & \multicolumn{3}{|c|}{$\begin{array}{l}\text { PollyVote Forecast by Horizon } \\
\text { Days to Election Day }\end{array}$} & \multirow[t]{2}{*}{$\mathrm{MAE}^{\mathrm{b}}$} \\
\hline & & 100 & 60 & 30 & \\
\hline $1992^{c}$ & \multirow{6}{*}{$\begin{array}{l}46.5 \\
54.7 \\
50.3 \\
51.2 \\
46.3 \\
51.9\end{array}$} & 54.0 & 49.6 & 47.9 & 3.9 \\
\hline $1996^{c}$ & & 56.9 & 55.6 & 56.2 & 1.7 \\
\hline $2000^{c}$ & & 50.7 & 52.4 & 52.4 & 1.5 \\
\hline $2004^{d}$ & & 52.8 & 51.5 & 52.0 & 0.9 \\
\hline $2008^{d}$ & & 48.6 & 48.1 & 47.6 & 1.8 \\
\hline $2012^{d}$ & & 51.7 & 51.6 & 51.8 & 0.02 \\
\hline \multicolumn{2}{|c|}{$\begin{array}{l}\text { MAE at } 100,60, \text { or } 30 \text { days to } \\
\text { election, all years. }\end{array}$} & \multirow[t]{2}{*}{2.4} & 1.4 & 1.2 & 1.65 \\
\hline \multicolumn{2}{|c|}{$\begin{array}{l}\text { MAE, at } 100,60, \text { or } 30 \text { days to } \\
\text { election, last three years. }\end{array}$} & & 0.8 & 0.7 & 0.91 \\
\hline \multicolumn{6}{|c|}{$\begin{array}{l}\text { Notes: } \\
\text { a Source: Dave Leip's “Atlas of U.S. Presidential Elections" } \\
\text { (uselectionatlas.org). } \\
\text { b MAE across the three horizons, by year. } \\
\text { c Post-dictions, i.e., these "forecasts" were calculated retrospectively, with } \\
\text { only three components, the only ones available then: polls, the IEM, and } \\
\text { econometric models. } \\
\text { d Predictions. i.e., these were forecasts in real time with four components, } \\
\text { the previously mentioned three plus a panel of experts. }\end{array}$} \\
\hline
\end{tabular}

